\title{
FAKTOR-FAKTOR YANG BERHUBUNGAN DENGAN KEGEMUKAN PADA ANAK BALITA 24-59 BULAN DI INDONESIA TAHUN 2010
}

(Analisis lanjut Riskesdas 2010)

\author{
Farida Kusumaningrum, Sudikno \\ Centre of Public Health Intervention Technology, \\ National Institute of Health Research and Development, Ministry of Health, Jakarta
}

\begin{abstract}
ABSTRAK
Penelitian ini bertujuan untuk mengetahui faktor-faktor yang berhubungan dengan kegemukan pada anak usia 24-59 bulan di Indonesia tahun 2010. Variabel penelitian meliputi: karakteristik anak, asupan energi dan zat gizi, karakteristik ibu, dan karakteristik keluarga. Disain penelitian yang digunakan adalah crosssectional dengan menggunakan data sekunder Riset Kesehatan Dasar (Riskesdas) 2010. Populasi penelitian ini adalah seluruh anggota rumah tangga yang berumur 24-59 bulan di 33 provinsi di Indonesia, sedangkan sampel adalah anggota rumah tangga yang berumur 24-59 bulan terpilih yang berjumlah 9.576 anak. Hasil penelitian menunjukkan prevalensi kegemukan pada anak usia 24-59 bulan sebesar 12,9 persen. Hasil uji statistik menunjukkan ada hubungan yang bermakna antara asupan protein, tingkat pendidikan ibu, status pekerjaan ibu, jumlah anggota keluarga, dan wilayah tempat tinggal dengan kegemukan pada anak usia 24-59 bulan $(p<0,05)$. Namun, tidak mendapatkan hubungan yang bermakna antara umur, jenis kelamin, berat lahir, asupan energi, asupan lemak, asupan karbohidrat, asupan serat, status gizi ibu, dan jumlah balita dengan kegemukan pada anak usia 24-59 bulan.
\end{abstract}

Kata kunci: faktor risiko, kegemukan, anak usia 24-59 bulan

\section{ABSTRACT}

\section{FACTORS ASSOCIATED TO OBESITY AMONG UNDERFIVE CHILDREN AGED 24-59 MONTHS IN INDONESIAN, 2010 \\ (Advance Analysis of 2010 Riskesdas Data)}

The objective of the study is to determine factors associated to obesity in children aged 24-59 months in Indonesia in 2010. The variables of study include: child characteristics, energy and nutrient intakes, characteristics of mother, and family characteristics. This is a cross-sectional study using secondary data of Riskesdas 2010. The study population was all household members aged 24-59 months in 33 provinces, while the sample was selected members of the household aged 24-59 months. The total samples were 9,576 children. The results showed that the prevalence of obesity among children was 12.9 percent. Statistical analysis showed that there was no significant association between protein intake, mother's education level, mother's employment status, number of family members, and residences of the children with obesity. However, there was no significant relationship between age, sex, birth weight, energy, fat, carbohydrate and fiber intakes, nutritional status of mothers, and number of children with obesity.

Keywords: risk factors, obesity, children aged 24-59 months

\section{PENDAHULUAN}

S aat ini dunia sedang menghadapi "beban ganda" masalah gizi. Masalah penyakit infeksi dan gizi kurang belum sepenuhnya teratasi, pada saat yang sama juga terjadi kenaikan yang cepat pada masalah gizi lebih atau kegemukan, begitu pula halnya yang terjadi di Indonesia. ${ }^{1}$

Kegemukan pada anak balita menjadi fokus perhatian masalah gizi. Masa balita merupakan periode penting dalam tumbuh kembang anak, karena pada masa ini terjadi pertumbuhan dasar yang akan mempengaruhi dan menentukan perkembangan anak selanjutnya. ${ }^{2}$ Anak pada usia 24-59 bulan sudah mengonsumsi makanan keluarga dan juga sudah dapat memilih dan menentukan sendiri makanan yang ingin dikonsumsi. Hal ini akan berdampak pada status gizi mereka. Selain itu anak pada usia 24-59 bulan diasumsikan sudah tidak mengonsumsi air susu ibu (ASI), sehingga 
asupan energi, dan zat gizi makro lain dalam ASI sangat sulit diperhitungkan. Dengan demikian bias dalam penilaian konsumsi individu bisa diminimalisasi. ${ }^{3}$

Banyak orang tua tidak menyadari bahwa kegemukan berdampak buruk terhadap tumbuh kembang anak selanjutnya. Menurut Samsudin, anak perempuan yang mengalami obesitas akan mendapat menarche (haid untuk pertama kali) pada usia yang lebih dini. ${ }^{4}$ Kegemukan pada anak berisiko tinggi menjadi obesitas pada masa dewasa dan berpotensi mengalami berbagai macam penyebab kesakitan dan kematian seperti penyakit degeneratif diantaranya penyakit kardiovaskuler, diabetes mellitus tipe-2, hipertensi, dan gangguan psikiatri. ${ }^{5}$ Gangguan psikiatri pada anak kegemukan umumnya masih terbatas pada gangguan psikososial. Anak kegemukan mengalami keterbatasan dalam pergaulan, keterbatasan berpartisipasi dalam berbagai jenis kegiatan olahraga, dan adanya dermatitis pada lipatan kulit yang mengakibatkan bau badan yang tidak enak dan tidak disukai oleh teman-temannya sehingga mereka lebih cenderung untuk menyendiri. ${ }^{4}$

Kegemukan didefinisikan sebagai akumulasi lemak berlebihan atau abnormal yang dapat mengganggu kesehatan. ${ }^{6}$ Istilah obesitas dan overweight sering digunakan untuk menggambarkan anak-anak dengan gizi lebih sebenarnya mempunyai arti yang berbeda. Obesitas adalah untuk menggambarkan individu dengan berat badan menurut tinggi badan lebih besar 120 persen dari standar, sedangkan overweight mempunyai batasan 110-120 persen standar. ${ }^{7}$ Pada tahun 1997, WHO menyatakan bahwa kegemukan telah menjadi masalah kesehatan masyarakat dunia. Prevalensi kegemukan pada anak terutama balita terus meningkat dari tahun ke tahun. Pada tahun 2005 setidaknya ada 20 juta anak balita di dunia yang mengalami kegemukan. ${ }^{6}$ Diperkirakan pada tahun 2010, jumlah anak balita yang mengalami kegemukan mencapai lebih dari 42 juta anak. ${ }^{8}$ Pada tahun 2030 prevalensi kegemukan di Amerika Serikat diprediksi meningkat antara 30-42 persen. ${ }^{9}$

Dalam tiga puluh tahun terakhir satu dari tiga anak-anak di Amerika Serikat termasuk dalam kategori gemuk atau obesitas. Lebih dari 10 persen dari anak-anak AS di bawah usia dua tahun sudah obesitas dan 20 persen dari anakanak usia 2 - 5 tahun kelebihan berat badan. ${ }^{10}$

Data hasil Survey Kesehatan Rumah Tangga Tahun 2004 menunjukkan bahwa kejadian balita gemuk di Indonesia menurut indikator $\mathrm{BB} / \mathrm{TB}$ adalah sebesar 3,5 persen. ${ }^{11}$ Berdasarkan data hasil Riset Kesehatan Dasar (Riskesdas) tahun 2007, prevalensi anak balita yang mengalami kegemukan adalah sebesar 12,2 persen, kemudian meningkat menjadi 14,0 persen di tahun 2010.3,12

Kegemukan dipengaruhi oleh berbagai macam faktor risiko. Berbagai teori menyatakan keterkaitan antara asupan energi dan zat gizi, umur, jenis kelamin, berat lahir, aktivitas fisik, status gizi ibu, tingkat pendidikan ibu, status bekerja ibu, jumlah anggota keluarga, jumlah balita, dan wilayah tempat tinggal dengan kegemukan pada balita. ${ }^{13,14}$

Kelebihan energi akan diubah menjadi lemak tubuh sehingga menyebabkan kegemukan. ${ }^{15}$ Penelitian Supriyatna (2004) membuktikan adanya hubungan antara asupan energi lebih dengan kegemukan pada anak usia 24-60 bulan. ${ }^{16}$ Begitu pula halnya dengan makanan yang tinggi protein biasanya tinggi lemak, sehingga konsumsi protein secara berlebihan dapat menyebabkan kegemukan. ${ }^{17}$ Penelitian Daryono (2003) melaporkan bahwa terdapat hubungan antara asupan protein yang lebih dengan kegemukan pada anak. ${ }^{18}$ Makanan tinggi lemak akan lebih menyebabkan kegemukan karena akan menghasilkan kalori lebih besar. ${ }^{19}$ Pemakaian energi yang kurang pada anak-anak terjadi karena kurang akivitas fisik, seperti menonton televisi seharian sambil makan cemilan, maka kecenderungan anak untuk menjadi gemuk akan lebih besar. ${ }^{2}$

Tingginya prevalensi dan banyaknya faktor yang menjadi penyebab kegemukan pada anak balita terutama usia 24-59 bulan melatarbelakangi studi ini untuk mengetahui gambaran prevalensi dan faktor-faktor risiko yang berhubungan dengan kegemukan pada anak usia 24-59 bulan di Indonesia pada tahun 2010 berdasarkan hasil Riskesdas 2010. Penelitian ini bertujuan untuk mengetahui faktor-faktor yang berhubungan dengan kegemukan pada anak usia 24-59 bulan berdasarkan Riskesdas tahun 2010. 


\section{METODE PENELITIAN}

Penelitian ini menggunakan data Riskesdas 2010 dengan disain cross-sectional. Kegiatan Riskesdas 2010 telah dilakukan sejak bulan Mei sampai pertengahan Agustus tahun 2010 di 33 provinsi yang tersebar di 441 kabupaten/kota dari total 497 kabupaten/kota di Indonesia.

Riset Kesehatan Dasar (Riskesdas) merupakan riset kesehatan berbasis komunitas yang dirancang dapat berskala nasional, propinsi, dan kabupaten/kota yang dilaksanakan secara periodik (3 tahun sekali) dengan tujuan untuk mengevaluasi pencapaian program kesehatan sekaligus bahan perencanaan kesehatan. Riset ini dilakukan oleh Badan Penelitian dan Pengembangan Kesehatan (Badan Litbangkes) Kementerian Kesehatan RI dalam upaya menyediakan data kesehatan yang berkesinambungan. Riskesdas 2010 berfokus pada pengumpulan data untuk mengevaluasi keberhasilan pencapaian target Millenium Development Goals (MDGs). ${ }^{3}$

Populasi penelitian meliputi semua anggota rumah tangga Riskesdas 2010 yang berumur 24-59 bulan. Sedangkan sampel adalah setiap anggota rumah tangga yang berumur 24-59 bulan dengan data-data lengkap.

Analisis data dilakukan secara univariat dan bivariat dengan menggunakan perangkat lunak statistik. Analisis univariat dilakukan untuk menjelaskan karakteristik masing-masing variabel yang diteliti baik variabel dependen maupun variabel independen. Analisis ini disajikan dalam bentuk tabel proporsi. Sedangkan analisis bivariat dilakukan untuk mengetahui hubungan antara variabel independen dengan variabel dependen. untuk variabel independen dan dependen yang bersifat katagorik, maka uji statistik yang digunakan untuk mengetahui hubungan dua variabel tersebut adalah Chi Square. ${ }^{20}$

\section{HASIL}

Prevalensi Kegemukan Anak Usia 24-59 bulan

Status gizi anak usia 24-59 bulan dalam penelitian ini dinilai berdasarkan indikator berat badan menurut tinggi badan (BB/TB). Bila nilai Z-score < -3 standar deviasi (SD) termasuk kategori sangat kurus, $\geq-3 \mathrm{SD}$ s/d $<-2 \mathrm{SD}$ tergolong kurus, $\geq-2 \mathrm{SD}$ s/d $\leq 2 \mathrm{SD}$ tergolong normal, dan bila $>2$ SD termasuk kategori gemuk. Hasil penelitian menunjukkan rata-rata nilai Z-score status gizi anak usia 24-59 bulan adalah $-0,0387 \mathrm{SD}$, dengan nilai Z-score terendah $-4,99 \mathrm{SD}$ dan tertinggi $5,00 \mathrm{SD}$.

Tabel 1

Distribusi Status Gizi Anak Usia 24-59 bulan di Indonesia Tahun 2010

\begin{tabular}{lcc}
\hline \multicolumn{1}{c}{ Status Gizi } & $\begin{array}{c}\text { Jumlah } \\
(\mathrm{n}=9576)\end{array}$ & Persentase $(\%)$ \\
\hline Sangat Kurus & 485 & 5,1 \\
Kurus & 599 & 6,3 \\
Normal & 7260 & 75,8 \\
Gemuk & 1232 & 12,9 \\
\hline
\end{tabular}

Selanjutnya status gizi hanya dibagi menjadi dua kategori saja yaitu gemuk dan tidak gemuk. Kategori sangat kurus, kurus, dan normal dimasukkan ke dalam kategori tidak gemuk, sehingga terlihat bahwa prevalensi kegemukan pada anak usia 24-59 bulan adalah sebesar 12,9 persen (Tabel 1).

\section{Karakteristik Sampel}

Gambaran karakteristik sampel secara rinci dijelaskan dalam Tabel 2. Rata-rata umur anak adalah 40,78 bulan dengan standar deviasi 10,247 bulan. Menurut jenis kelamin diketahui bahwa sampel terbanyak yaitu anak berjenis kelamin laki-laki $(50,3 \%)$ dibandingkan perempuan $(49,7 \%)$. Selanjutnya untuk variabel berat lahir dikelompokkan menjadi tiga, yaitu: di atas normal $(>4 \mathrm{~kg})$, berat lahir normal $(2,5-4$ $\mathrm{kg})$, dan BBLR $(<2,5 \mathrm{~kg})$. Dari Tabel 2 terlihat bahwa berat lahir anak lebih banyak dalam kategori normal $(90,9 \%)$ dibandingkan yang berat badannya di atas normal yang hanya 
sebesar 2,9 persen, maupun anak yang lahir $\operatorname{BBLR}(6,2 \%)$.

\section{Asupan Energi dan Zat Gizi}

Berdasarkan Tabel 3 terlihat bahwa persentase asupan energi total dalam sehari anak lebih banyak yang masuk dalam kategori lebih dari 100\% AKG yaitu sebanyak 37,9 persen. Begitu pula halnya dengan proporsi asupan protein, mayoritas anak mengonsumsi lebih dari $100 \%$ AKG $(60,3 \%)$ dan lemak lebih dari $25 \%$ total energi sebesar 43,9 persen. Separuh lebih anak mengonsumsi karbohidrat kurang dari $50 \%$ total energi yaitu sebesar 55,8 persen. Proporsi anak dengan asupan serat kurang dari $10 \mathrm{~g} / 1000 \mathrm{kkal}$ lebih banyak dibandingkan anak dengan asupan serat cukup yaitu sebesar 96,9 persen.

Tabel 2

Distribusi Karakteristik Anak Usia 24-59 bulan di Indonesia Tahun 2010

\begin{tabular}{ccc}
\hline $\begin{array}{c}\text { Karakteristik } \\
\text { Anak }\end{array}$ & $\begin{array}{c}\text { Jumlah } \\
(\mathrm{n}=9576)\end{array}$ & Persentase (\%) \\
\hline $\begin{array}{c}\text { Jenis Kelamin } \\
\text { Perempuan }\end{array}$ & 4759 & 49,7 \\
Laki-laki & 4817 & 50,3 \\
Berat lahir & & \\
$>4 \mathrm{~kg}$ & 279 & 2,9 \\
$2,5-4 \mathrm{~kg}$ & 8707 & 90,9 \\
$<2,5 \mathrm{~kg}$ & 590 & 6,2 \\
\hline
\end{tabular}

Tabel 3

Distribusi Asupan Energi dan Zat Gizi Anak Usia 24-59 Bulan di Indonesia Tahun 2010

\begin{tabular}{llll}
\hline \multicolumn{2}{c}{ Asupan Energi dan Zat Gizi } & $\begin{array}{c}\text { Jumlah } \\
(\mathrm{n}=9576)\end{array}$ & $\begin{array}{c}\text { Persentase } \\
(\%)\end{array}$ \\
\hline Asupan Energi & & 3629 & 37,9 \\
& $>100 \%$ AKG & 2757 & 28,8 \\
& $70-100 \%$ AKG & 3190 & 33,3 \\
Asupan Protein & $<70 \%$ AKG & & \\
& $>100 \%$ AKG & 5775 & 60,3 \\
& $80-100 \%$ AKG & 1320 & 13,8 \\
Asupan Lemak & $<80 \%$ AKG & 2481 & 25,9 \\
& $>25 \%$ TE & & \\
& $15-25 \%$ TE & 4201 & 43,9 \\
& $<15 \%$ TE & 2496 & 26,1 \\
Asupan Karbohidrat & 2879 & 30,1 \\
& $>60 \%$ TE & & \\
& $50-60 \%$ TE & 2818 & 29,4 \\
& $<50 \%$ TE & 1414 & 14,8 \\
Asupan Serat & $<10 \mathrm{~g} / 1000$ kkal & 5344 & 55,8 \\
& $\geq 10 \mathrm{~g} / 1000$ kkal & 9275 & 96,9 \\
\end{tabular}




\section{Gambaran Karakteristik lbu}

Karakteristik ibu meliputi status gizi yang dikategorikan menjadi gemuk, normal, dan kurus berdasarkan IMT; tingkat pendidikan yang dikategorikan menjadi tinggi, sedang, dan rendah; serta status pekerjaan ibu yang dikategorikan menjadi bekerja (TNI/POLRI, PNS/pegawai, wiraswasta/ layan jasa/ dagang, petani, buruh, lainnya) dan tidak bekerja (termasuk ibu dengan status sekolah).

Tabel 4

Distribusi Karakteristik Ibu dari Anak Usia 24-59 Bulan di Indonesia Tahun 2010

\begin{tabular}{ccc}
\hline Karakteristik Ibu & $\begin{array}{c}\text { Jumlah } \\
(\mathrm{n}=9576)\end{array}$ & $\begin{array}{c}\text { Persentase } \\
(\%)\end{array}$ \\
\hline Status Gizi Ibu & & \\
Gemuk & 3006 & 31,4 \\
Normal & 5824 & 60,8 \\
Kurus & 746 & 7,8 \\
Tinggi & & \\
Sedang & 969 & 10,1 \\
Rendah & 2930 & 30,6 \\
Status Pekerjaan Ibu & 5677 & 59,3 \\
Bekerja & & \\
Tidak Bekerja & 4686 & 48,9 \\
& 4890 & 51,1 \\
\hline
\end{tabular}

Berdasarkan Tabel 4 tampak bahwa proporsi status gizi ibu lebih banyak termasuk dalam kategori normal, yaitu sebesar 60,8 persen. Sedangkan menurut tingkat pendidikan, ibu dengan tingkat pendidikan rendah berjumlah paling banyak dibandingkan dengan pendidikan sedang dan tinggi yaitu sebesar 59,3 persen. Selanjutnya, menurut status pekerjaan ibu, hasil analisis menunjukkan bahwa proporsi ibu yang bekerja dan tidak bekerja tidak jauh berbeda.

\section{Karakteristik Keluarga}

Berdasarkan Tabel 5 terlihat bahwa persentase jumlah anggota keluarga lebih besar pada keluarga kecil ( $\leq 4$ orang) yaitu sebesar 52,3 persen. Sebagian besar keluarga dengan jumlah balita satu anak $(79,6 \%)$. Sedangkan menurut wilayah tempat tinggal persentasenya lebih banyak pada keluarga yang tinggal di perkotaan dibandingkan di wilayah perdesaan.

Tabel 5

Distribusi Karakteristik Keluarga dari Anak Usia 24-59 Bulan di Indonesia Tahun 2010

\begin{tabular}{ccc}
\hline Karakteristik Keluarga & $\begin{array}{c}\text { Jumlah } \\
(\mathrm{n}=9576)\end{array}$ & $\begin{array}{c}\text { Persentase } \\
(\%)\end{array}$ \\
\hline $\begin{array}{c}\text { Jumlah Anggota Keluarga } \\
\leq 4 \text { orang }\end{array}$ & 5005 & 52,3 \\
$\quad>4$ orang & 4571 & 47,7 \\
Jumlah Balita & & \\
1 orang & 7622 & 79,6 \\
$\quad$ 1 orang & 1954 & 20,4 \\
Wilayah Tempat Tinggal & & \\
Perkotaan & 5387 & 56,3 \\
Perdesaan & 4189 & 43,7 \\
\hline
\end{tabular}




\section{Hubungan Antara Karakteristik Anak dan Kegemukan}

Hasil uji statistik menunjukkan tidak adanya hubungan yang bermakna antara umur dengan kegemukan pada anak usia 24-59 bulan ( $p$ value> 0,05 ), namun ada peluang lebih besar anak yang lebih muda untuk mengalami kegemukan dibandingkan dengan anak yang lebih tua, terlihat dari rata-rata umur anak yang kegemukan lebih muda dibandingkan dengan anak yang tidak kegemukan. Secara rinci dapat dilihat pada Tabel 6 .

Tabel 6

Distribusi Rata-rata Umur (bulan) menurut Kegemukan Anak Usia 24-59 Bulan di Indonesia Tahun 2010

\begin{tabular}{lccccc}
\hline Kegemukan & Mean & SD & SE & $p$-value & $\mathrm{n}$ \\
\hline Ya & 40,38 & 10,074 & 0,287 & & 0,145 \\
Tldak & 40,84 & 10,272 & 0,112 & & 8344 \\
\hline
\end{tabular}

Berdasarkan hasil analisis tabulasi silang antara jenis kelamin dan kegemukan pada anak menunjukkan bahwa proporsi kegemukan pada anak perempuan adalah sebesar 13,0 persen. Angka ini lebih besar walaupun tidak berbeda terlalu jauh dibandingkan dengan proporsi kegemukan pada anak laki-laki yaitu sebesar 12,8 persen. Hasil uji statistik menunjukkan tidak adanya hubungan yang bermakna ( $p$ value > 0,05) antara jenis kelamin dengan kegemukan pada anak usia 24-59 bulan (Tabel 7).

Tabel 7

Hubungan Antara Karakteristik Anak dan Kegemukan pada Anak Usia 24-59 Bulan di Indonesia Tahun 2010

\begin{tabular}{|c|c|c|c|c|c|c|c|}
\hline \multirow{3}{*}{$\begin{array}{l}\text { Karakteristik } \\
\text { anak }\end{array}$} & \multicolumn{4}{|c|}{ Kegemukan } & \multirow{3}{*}{$p$-value } & \multirow{3}{*}{ OR } & \multirow{3}{*}{$95 \% \mathrm{Cl}$} \\
\hline & \multicolumn{2}{|c|}{$\mathrm{Ya}$} & \multicolumn{2}{|c|}{ Tidak } & & & \\
\hline & $\mathrm{n}$ & $\%$ & $\mathrm{n}$ & $\%$ & & & \\
\hline \multicolumn{8}{|l|}{ Jenis Kelamin } \\
\hline Perempuan* & 617 & 13,0 & 4142 & 87,0 & \multirow[b]{2}{*}{0,796} & \multirow{2}{*}{1,018} & \multirow{2}{*}{$0,903-1,147$} \\
\hline Laki-laki & 615 & 12,8 & 4202 & 87,2 & & & \\
\hline \multicolumn{8}{|l|}{ Berat lahir } \\
\hline$>4 \mathrm{~kg}^{*}$ & 36 & 12,9 & 243 & 87,1 & 0,063 & & \\
\hline $2,5-4 \mathrm{~kg}$ & 1138 & 13,1 & 7569 & 86,9 & & 0,736 & $0,473-1,146$ \\
\hline$<2,5 \mathrm{~kg}$ & 58 & 9,8 & 532 & 90,2 & & 0,725 & $0,549-0,958$ \\
\hline
\end{tabular}

Keterangan: ${ }^{*}=$ Reference

Tabel 7 juga menunjukkan bahwa proporsi kejadian kegemukan pada anak terbanyak adalah anak dengan berat lahir normal (2,5-4 $\mathrm{kg}$ ) sebesar 13,1 persen. Hasil uji statistik menunjukkan tidak terdapat hubungan yang bermakna antara berat lahir dengan kegemukan pada anak usia $24-59$ bulan ( $p$-value $>0,05)$.

\section{Hubungan Antara Asupan Energi dan Zat Gizi dengan Kegemukan}

Berdasarkan hasil analisis didapatkan proporsi kegemukan pada anak dengan asupan energi total per hari lebih dari 100\% AKG sebesar 13,4 persen. Sedangkan proporsi anak gemuk dengan asupan energi cukup (70-100\% AKG) dan kurang ( $<70 \%$ AKG) masing-masing sebesar 12,9 persen dan 12,2 persen. Hasil uji statistik menunjukkan tidak adanya hubungan yang bermakna antara asupan energi dengan kegemukan pada anak usia 24-59 bulan ( $p$ value $>0,05$ ). Untuk lebih jelasnya dapat dilihat pada Tabel 8.

Hasil analisis antara asupan protein dengan kegemukan, di mana proporsi anak 
gemuk dengan asupan protein lebih dari 100\% AKG sebesar 13,4 persen, sedangkan proporsi anak gemuk dengan asupan protein cukup (80$100 \%$ AKG) dan kurang (< $80 \%$ AKG) masingmasing sebesar 13,3 persen dan 11,4 persen. Hasil uji statistik menunjukkan adanya hubungan yang bermakna antara asupan protein dengan kegemukan pada anak usia 2459 bulan $(p$-value $<0,05)$. Anak dengan asupan protein cukup (80-100\% AKG) bersifat protektif
0,829 kali lebih besar terhadap kegemukan dibandingkan anak dengan asupan protein lebih dari 100\% AKG, dan anak dengan asupan protein $<80 \%$ AKG juga bersifat protektif terhadap kegemukan sebesar 0,834 kali lebih besar dibandingkan anak dengan aspan protein $>100 \%$ AKG. Dengan kata lain, anak dengan asupan protein cukup dan kurang berpeluang terlindung dari kegemukan dibandingkan anak dengan asupan protein tinggi.

Tabel 8

Hubungan Antara Asupan Energi dan Zat Gizi dengan Kegemukan pada Anak Usia 24-59 Bulan di Indonesia Tahun 2010

\begin{tabular}{|c|c|c|c|c|c|c|c|}
\hline \multirow{3}{*}{$\begin{array}{c}\text { Asupan Energi dan } \\
\text { Zat Gizi anak }\end{array}$} & \multicolumn{4}{|c|}{ Kegemukan } & \multirow{3}{*}{$p$-value } & \multirow{3}{*}{ OR } & \multirow{3}{*}{$95 \% \mathrm{Cl}$} \\
\hline & \multicolumn{2}{|c|}{$\mathrm{Ya}$} & \multicolumn{2}{|c|}{ Tidak } & & & \\
\hline & $\mathrm{n}$ & $\%$ & $n$ & $\%$ & & & \\
\hline \multicolumn{8}{|l|}{ Asupan Energi } \\
\hline$>100 \% \mathrm{AKG}^{*}$ & 488 & 13,4 & 3141 & 86,6 & \multirow[t]{3}{*}{0,286} & & \\
\hline 70-100\%AKG & 356 & 12,9 & 2401 & 87,1 & & 0,891 & $0,773-1,028$ \\
\hline$<70 \%$ AKG & 388 & 12,2 & 2802 & 87,8 & & 0,934 & $0,801-1,089$ \\
\hline \multicolumn{8}{|l|}{ Asupan Protein } \\
\hline$>100 \% \mathrm{AKG}^{*}$ & 774 & 13,4 & 5001 & 86,6 & \multirow[t]{3}{*}{0,035} & & \\
\hline 80-100\%AKG & 176 & 13,3 & 1144 & 86,7 & & 0,829 & $0,717-0,958$ \\
\hline$<80 \%$ AKG & 282 & 11,4 & 2199 & 88,6 & & 0,834 & $0,682-1,020$ \\
\hline \multicolumn{8}{|l|}{ Asupan Lemak } \\
\hline$>25 \% \mathrm{TE}^{*}$ & 544 & 12,9 & 3657 & 87,1 & \multirow[t]{3}{*}{0,239} & & \\
\hline 15- 25\% TE & 340 & 13,6 & 2156 & 86,4 & & 0,924 & $0,801-1,067$ \\
\hline$<15 \% \mathrm{TE}$ & 348 & 12,1 & 2531 & 87,9 & & 0,872 & $0,743-1,023$ \\
\hline \multicolumn{8}{|l|}{ Asupan Karbohidrat } \\
\hline$>60 \% \mathrm{TE}^{*}$ & 349 & 12,4 & 2469 & 87,6 & \multirow[t]{3}{*}{0,605} & & \\
\hline $50-60 \%$ TE & 180 & 12,7 & 1234 & 87,3 & & 1,072 & $0,934-1,229$ \\
\hline$<50 \%$ TE & 703 & 13,2 & 4641 & 86,8 & & 1,038 & $0,871-1,237$ \\
\hline \multicolumn{8}{|l|}{ Asupan Serat } \\
\hline$<10 \mathrm{~g} / 1000 \mathrm{kkal}^{*}$ & 1200 & 12,9 & 8075 & 87,1 & \multirow{2}{*}{0,276} & \multirow{2}{*}{1,249} & \multirow{2}{*}{$0,862-1,811$} \\
\hline$\geq 10 \mathrm{~g} / 1000 \mathrm{kkal}$ & 32 & 10,6 & 269 & 89,4 & & & \\
\hline
\end{tabular}

Tabel 8 menunjukkan bahwa proporsi anak gemuk dengan asupan lemak $>25 \%$ total energi adalah sebesar 12,9 persen. Tidak berbeda jauh dengan proporsi anak gemuk dengan asupan protein cukup ( $10-25 \%$ total energi) dan kurang $(<10 \%$ total energi) yaitu masingmasing sebesar 13,6 persen dan 12,1 persen. Hasil analisis menunjukkan tidak terdapat hubungan yang bermakna antara asupan lemak dengan kegemukan pada anak usia $24-59$ bulan ( $p$-value $>0,05)$.

Proporsi anak gemuk dengan asupan karbohidrat lebih dari $60 \%$ total energi adalah sebesar 12,4 persen. Angka tersebut sedikit lebih rendah dibandingkan dengan anak gemuk dengan asupan karbohidrat cukup (50-60\% total energi) dan kurang $(<50 \%$ total energi) yaitu masing-masing sebesar 12,7 persen dan 13,2 persen. Hasil uji statistik menunjukkan tidak adanya hubungan yang bermakna antara asupan karbohidrat dengan kegemukan pada anak usia 24-59 bulan ( $p$-value $>0,05)$.

Proporsi anak gemuk dengan asupan serat $<10 \mathrm{~g} / 1000$ kkal yaitu sebesar 12,9 persen, sedangkan proporsi anak gemuk dengan asupan serat $\geq 10 \mathrm{~g} / 1000$ kkal sebesar 10,6 persen. Hasil uji statistik menunjukkan tidak adanya hubungan yang bermakna antara 
asupan serat dengan kegemukan pada anak usia 24-59 bulan ( $p$-value > 0,05) (Tabel 8).

\section{Hubungan Antara Karakteristik Ibu dan Kegemukan}

Berdasarkan hasil analisis antara karakteristik ibu dengan kegemukan pada anak, menurut variabel status gizi ibu didapatkan proporsi anak gemuk yang memiliki ibu dengan status gizi gemuk sebesar 12,4 persen. Sedangkan proporsi anak gemuk yang memiliki ibu dengan status gizi normal dan kurang masing-masing sebesar 13,3 persen dan 11,1 persen. Hasil uji statistik menunjukkan tidak terdapat hubungan yang bermakna antara status gizi ibu dengan kegemukan pada anak usia $24-59$ bulan ( $p$-value $>0,05)$. Untuk lebih jelasnya dapat dilihat pada Tabel 9 .

Tabel 9

Hubungan Antara Karakteristik Ibu dan Kegemukan pada Anak Usia 24 - 59 Bulan di Indonesia Tahun 2010

\begin{tabular}{|c|c|c|c|c|c|c|c|}
\hline \multirow{3}{*}{$\begin{array}{l}\text { Karakteristik } \\
\text { Ibu }\end{array}$} & \multicolumn{4}{|c|}{ Kegemukan } & \multirow{3}{*}{$p$-value } & \multirow{3}{*}{ OR } & \multirow{3}{*}{$95 \% \mathrm{Cl}$} \\
\hline & \multicolumn{2}{|c|}{$\mathrm{Ya}$} & \multicolumn{2}{|c|}{ Tidak } & & & \\
\hline & $\mathrm{n}$ & $\%$ & $\mathrm{n}$ & $\%$ & & & \\
\hline \multicolumn{8}{|l|}{ Status Gizi Ibu } \\
\hline Gemuk* & 374 & 12,4 & 2632 & 87,6 & \multirow[t]{3}{*}{0,174} & & \\
\hline Normal & 775 & 13,3 & 5049 & 86,7 & & 0,881 & $0,684-1,134$ \\
\hline Kurus & 83 & 11,1 & 663 & 88,9 & & 0,816 & $0,641-1,037$ \\
\hline \multicolumn{8}{|l|}{ Pendidikan lbu } \\
\hline Tinggi* & 164 & 16,9 & 805 & 83,1 & \multirow[t]{3}{*}{0,000} & & \\
\hline Sedang & 391 & 13,3 & 2539 & 86,7 & & 0,665 & $0,552-0,801$ \\
\hline Rendah & 677 & 11,9 & 5000 & 88,1 & & 0,879 & $0,769-1,005$ \\
\hline \multicolumn{8}{|l|}{ Status Pekerjaan Ibu } \\
\hline Bekerja* & 650 & 13,9 & 4036 & 86,1 & \multirow{2}{*}{0,004} & \multirow{2}{*}{1,192} & \multirow{2}{*}{$1,058-1,344$} \\
\hline Tidak Bekerja & 582 & 11,9 & 4308 & 88,1 & & & \\
\hline
\end{tabular}

Hasil analisis antara tingkat pendidikan ibu dengan kegemukan pada anak menunjukkan proporsi anak gemuk yang memiliki ibu dengan status pendidikan ibu tinggi adalah yang terbesar dibandingkan anak dengan pendidikan ibu rendah dan sedang yaitu sebesar 16,9 persen (Tabel 9). Hasil analisis menunjukkan adanya hubungan yang bermakna antara tingkat pendidikan ibu dengan kejadian kegemukan pada anak usia 24-59 bulan ( $p$ value $<0,05)$. Anak dari ibu dengan tingkat pendidikan rendah bersifat protektif 0,879 kali lebih besar terhadap kegemukan dibandingkan anak dari ibu dengan tingkat pendidikan tinggi, dan anak dari ibu dengan tingkat pendidikan sedang bersifat protektif 0,665 kali lebih besar terhadap kegemukan dibandingkan anak dengan ibu yang berpendidikan tinggi.

Tabel 9 juga menunjukkan proporsi ibu bekerja yang mempunyai anak gemuk sebesar 13,9 persen, lebih tinggi dibandingkan dengan proporsi ibu yang tidak bekerja yang memiliki anak gemuk yaitu sebesar 11,9 persen. Hasil uji statistik mendapatkan adanya hubungan yang bermakna antara status pekerjaan ibu dengan kejadian kegemukan pada anak usia 24-59 bulan ( $p$-value $<0,05$ ). Anak yang memiliki ibu bekerja berpeluang 1,192 kali lebih besar untuk mengalami kegemukan dibandingkan dengan anak yang memiliki ibu tidak bekerja.

\section{Hubungan Antara Karakteristik Keluarga dan Kegemukan}

Tabel 10 menyajikan hasil analisis antara karakteristik keluarga dengan kegemukan. Proporsi anak yang mengalami kegemukan dengan jumlah anggota keluarga $\leq 4$ orang sebesar 13,9 persen. Sedangkan proporsi anak yang mengalami kegemukan dengan jumlah anggota keluarga lebih dari 4 orang sebesar 11,8 persen. Hasil uji statistik menunjukkan adanya hubungan yang bermakna antara jumlah anggota keluarga dengan kegemukan pada anak usia $24-59$ bulan $(p$-value $<0,05) \mathrm{di}$ 
mana anak dengan jumlah anggota keluarga $\leq 4$ orang berpeluang mengalami kegemukan 1,207 kali lebih besar dibandingkan anak dengan jumlah anggota keluarga $>4$ orang.

Hasil analisis menunjukkan proporsi kegemukan pada anak yang di rumahnya terdapat jumlah balita $\leq 1$ orang sebesar 13,0 persen, sedangkan proporsi kegemukan pada anak yang di rumahnya terdapat jumlah balita lebih dari satu anak sebesar 12,4 persen (Tabel 10).

Hasil analisis menunjukkan tidak terdapat hubungan yang bermakna antara jumlah balita dalam rumah tangga dengan kejadian kegemukan pada anak usia 24-59 bulan ( $p$ value $>0,05)$.

Tabel 10

Hubungan Antara Karakteristik Keluarga dan Kejadian Kegemukan pada Anak Usia 24 - 59 Bulan di Indonesia Tahun 2010

\begin{tabular}{|c|c|c|c|c|c|c|c|}
\hline \multirow{3}{*}{$\begin{array}{l}\text { Karkteristik } \\
\text { Keluarga }\end{array}$} & \multicolumn{4}{|c|}{ Kegemukan } & \multirow{3}{*}{$p$-value } & \multirow{3}{*}{ OR } & \multirow{3}{*}{$95 \% \mathrm{Cl}$} \\
\hline & \multicolumn{2}{|c|}{$\mathrm{Ya}$} & \multicolumn{2}{|c|}{ Tidak } & & & \\
\hline & $\mathrm{n}$ & $\%$ & $\mathrm{n}$ & $\%$ & & & \\
\hline \multicolumn{8}{|l|}{$\begin{array}{l}\text { Jumlah Anggota } \\
\text { Keluarga }\end{array}$} \\
\hline$\leq 4$ orang ${ }^{*}$ & 694 & 13,9 & 4311 & 86,1 & \multirow{2}{*}{0,002} & \multirow{2}{*}{1,207} & \multirow{2}{*}{$1,070-1,361$} \\
\hline$>4$ orang & 538 & 11,8 & 4033 & 88,2 & & & \\
\hline \multicolumn{8}{|l|}{ Jumlah Balita } \\
\hline$\leq 1$ orang ${ }^{*}$ & 989 & 13,0 & 6633 & 87,0 & \multirow{2}{*}{0,550} & \multirow{2}{*}{1,050} & \multirow{2}{*}{$0,904-1,220$} \\
\hline$>1$ orang & 243 & 12,4 & 1711 & 87,6 & & & \\
\hline \multicolumn{8}{|c|}{ Wilayah Tempat Tinggal } \\
\hline Perkotaan* & 767 & 14,2 & 4620 & 85,8 & \multirow{2}{*}{0,000} & \multirow{2}{*}{1,330} & \multirow{2}{*}{$1,176-1,504$} \\
\hline Perdesaan & 465 & 11,1 & 3724 & 88,9 & & & \\
\hline
\end{tabular}

Hasil analisis antara wilayah tempat tinggal dengan kejadian kegemukan pada anak, didapatkan proporsi anak gemuk dengan keluarga yang tinggal di perkotaan sebesar 14,2 persen, sedangkan proporsi anak gemuk yang tinggal di perdesaan sebesar 11,1 persen. Hasil uji statistik menunjukkan adanya hubungan yang bermakna antara wilayah tempat tinggal dengan kejadian kegemukan pada anak usia 24-59 bulan ( $p$-value $<0,05)$.

Anak yang tinggal di perkotaan berpeluang 1,330 kali lebih besar untuk mengalami kegemukan dibandingkan dengan anak yang tinggal di perdesaan. 
Tabel 11

Rekapitulasi Hasil Analisis Bivariat antara Faktor-Faktor Risiko dengan Kegemukan pada Anak Usia 24 - 59 Bulan

\begin{tabular}{|c|c|c|c|c|c|c|c|}
\hline \multirow{3}{*}{$\begin{array}{l}\text { Faktor } \\
\text { Resiko }\end{array}$} & \multicolumn{4}{|c|}{ Kegemukan } & \multirow{3}{*}{$\begin{array}{c}p- \\
\text { value }\end{array}$} & \multirow{3}{*}{ OR } & \multirow{3}{*}{$95 \% \mathrm{Cl}$} \\
\hline & \multicolumn{2}{|c|}{$\mathrm{Ya}$} & \multicolumn{2}{|c|}{ Tidak } & & & \\
\hline & $\mathrm{n}$ & $\%$ & $\mathrm{n}$ & $\%$ & & & \\
\hline Umur & $\begin{array}{l}\text { Mean } \\
40,38\end{array}$ & 12,9 & $\begin{array}{l}\text { Mean } \\
40,84\end{array}$ & 87,1 & 0,145 & & \\
\hline \multicolumn{8}{|l|}{ Jenis Kelamin Anak } \\
\hline Perempuan* & 617 & 13,0 & 4142 & 87,0 & \multirow{2}{*}{0,796} & \multirow{2}{*}{1,018} & \multirow{2}{*}{$0,903-1,147$} \\
\hline Laki-laki & 615 & 12,8 & 4202 & 87,2 & & & \\
\hline \multicolumn{8}{|l|}{ Berat lahir Anak } \\
\hline$>4 \mathrm{~kg}^{*}$ & 36 & 12,9 & 243 & 87,1 & 0,063 & & \\
\hline $2,5-4 \mathrm{~kg}$ & 1138 & 13,1 & 7569 & 86,9 & & 0,736 & $0,473-1,146$ \\
\hline$<2,5 \mathrm{~kg}$ & 58 & 9,8 & 532 & 90,2 & & 0,725 & $0,549-0,958$ \\
\hline \multicolumn{8}{|l|}{ Asupan Energi Anak } \\
\hline$>100 \% \mathrm{AKG}^{*}$ & 488 & 13,4 & 3141 & 86,6 & 0,286 & & \\
\hline $70-100 \%$ AKG & 356 & 12,9 & 2401 & 87,1 & & 0,891 & $0,773-1,028$ \\
\hline$<70 \%$ AKG & 388 & 12,2 & 2802 & 87,8 & & 0,934 & $0,801-1,089$ \\
\hline \multicolumn{8}{|l|}{ Asupan Protein Anak } \\
\hline$>100 \%$ AKG $^{*}$ & 774 & 13,4 & 5001 & 86,6 & 0,035 & & \\
\hline $80-100 \%$ AKG & 176 & 13,3 & 1144 & 86,7 & & 0,829 & $0,717-0,958$ \\
\hline$<80 \%$ AKG & 282 & 11,4 & 2199 & 88,6 & & 0,834 & $0,682-1,020$ \\
\hline \multicolumn{8}{|l|}{ Asupan Lemak Anak } \\
\hline$>25 \% \mathrm{TE}^{*}$ & 544 & 12,9 & 3657 & 87,1 & 0,239 & & \\
\hline 15- $25 \%$ TE & 340 & 13,6 & 2156 & 86,4 & & 0,924 & $0,801-1,067$ \\
\hline$<15 \%$ TE & 348 & 12,1 & 2531 & 87,9 & & 0,872 & $0,743-1,023$ \\
\hline \multicolumn{8}{|c|}{ Asupan Karbohidrat Anak } \\
\hline$>60 \% \mathrm{TE}^{*}$ & 349 & 12,4 & 2469 & 87,6 & 0,605 & & \\
\hline $50-60 \%$ TE & 180 & 12,7 & 1234 & 87,3 & & 1,072 & $0,934-1,229$ \\
\hline$<50 \%$ TE & 703 & 13,2 & 4641 & 86,8 & & 1,038 & $0,871-1,237$ \\
\hline \multicolumn{8}{|l|}{ Asupan Serat Anak } \\
\hline$<10 \mathrm{~g} / 1000 \mathrm{kkal}^{*}$ & 1200 & 12,9 & 8075 & 87,1 & & & \\
\hline$\geq 10 \mathrm{~g} / 1000 \mathrm{kkal}$ & 32 & 10,6 & 269 & 89,4 & $0,2 / 6$ & 1,249 & $0,862-1,811$ \\
\hline \multicolumn{8}{|l|}{ Status Gizi lbu } \\
\hline Gemuk $^{*}$ & 374 & 12,4 & 2632 & 87,6 & 0,174 & & \\
\hline Normal & 775 & 13,3 & 5049 & 86,7 & & 0,881 & $0,684-1,134$ \\
\hline Kurus & 83 & 11,1 & 663 & 88,9 & & 0,816 & $0,641-1,037$ \\
\hline \multicolumn{8}{|c|}{ Tingkat Pendidikan Ibu } \\
\hline Tinggi $^{*}$ & 164 & 16,9 & 805 & 83,1 & 0,000 & & \\
\hline Sedang & 391 & 13,3 & 2539 & 86,7 & & 0,665 & $0,552-0,801$ \\
\hline Rendah & 677 & 11,9 & 5000 & 88,1 & & 0,879 & $0,769-1,005$ \\
\hline \multicolumn{8}{|l|}{ Status Pekerjaan Ibu } \\
\hline Bekerja* & 650 & 13,9 & 4036 & 86,1 & 0,004 & 1,192 & $1,058-1,344$ \\
\hline Tidak Bekerja & 582 & 11,9 & 4308 & 88,1 & & & \\
\hline Jumlah Anggota Kell & & & & & & & \\
\hline$\leq 4$ orang $^{*}$ & 694 & 13,9 & 4311 & 86,1 & 0,002 & 1,207 & $1,070-1,361$ \\
\hline$>4$ orang & 538 & 11,8 & 4033 & 88,2 & & & \\
\hline Jumlah Balita & & & & & & & \\
\hline$\leq 1$ orang* & 989 & 13,0 & 6633 & 87,0 & 0,550 & 1,050 & $0,904-1,220$ \\
\hline$>1$ orang & 243 & 12,4 & 1711 & 87,6 & & & \\
\hline Wilayah Tempat Ting & & & & & & & \\
\hline Perkotaan* & 767 & 14,2 & 4620 & 85,8 & 0,000 & 1,330 & $1,176-1,504$ \\
\hline Perdesaan & 465 & 11,1 & 3724 & 88,9 & & & \\
\hline
\end{tabular}




\section{BAHASAN}

Data yang digunakan dalam penelitian ini merupakan data sekunder Riskesdas 2010. Sebagaimana penggunaan data sekunder dalam analisis data, penelitian ini memiliki kekurangan dan keterbatasan terutama menyangkut variabel independen yang diteliti terbatas pada variabel-variabel yang ada pada kuesioner Riskesdas 2010 saja, sehingga variabel lain yang mungkin berpengaruh cukup besar terhadap kejadian kegemukan pada anak usia 24-59 bulan seperti aktivitas fisik dan status gizi ayah tidak dapat dianalisis dalam penelitian ini. Selain keterbatasan yang menyangkut variabel independen, penelitian ini juga memiliki keterbatasan dalam pengukuran konsumsi makanan individu. Metode yang dilakukan dalam Riskesdas 2010 adalah food recall 24 jam yang hanya dilakukan satu hari saja. Padahal salah satu kelemahan metode food recall 24 jam adalah tidak dapat menggambarkan asupan makanan sehari-hari, bila hanya dilakukan recall satu hari. ${ }^{21}$ Selain itu, kelemahan lain dari metode food recall 24 jam adalah the flat slope syndrome yaitu kecenderungan bagi responden yang kurus untuk melaporkan konsumsinya lebih banyak dan bagi responden yang gemuk cenderung melaporkan lebih sedikit terutama makanan yang mengandung lemak tinggi. Dengan demikian, dapat dikatakan bahwa pengukuran tersebut tidak terlalu menggambarkan asupan sehari-hari anak yang menjadi sampel dalam penelitian ini.

Berdasarkan hasil penelitian ini, prevalensi kegemukan anak usia 24-59 bulan di Indonesia pada tahun 2010 adalah sebesar 12,9 persen. Prevalensi tersebut sedikit lebih tinggi dibandingkan prevalensi kegemukan pada balita (0-59 bulan) pada tahun 2007, yaitu sebesar 12,2 persen. ${ }^{12}$ Namun, bila dibandingkan dengan hasil SKRT tahun 2004 prevalensi tersebut meningkat tajam. Hasil SKRT 2004 mendapatkan kejadian balita gemuk dengan indikator yang sama yaitu BB/TB sebesar 3,5 persen. ${ }^{11}$ Peningkatan prevalensi tersebut menggambarkan bahwa kegemukan sudah menjadi masalah kesehatan masyarakat dan telah terjadi beban ganda masalah gizi di Indonesia. Kegemukan di masa anak-anak merupakan salah satu penyebab kejadian penyakit kardiovaskuler dan penyebab kematian lainnya di masa dewasa. ${ }^{22}$

Usia yang dipilih dalam penelitian ini adalah 24-59 bulan karena pada usia ini anak sudah makan makanan keluarga dan sudah dapat memilih dan menentukan sendiri makanan yang ingin dikonsumsi sehingga akan berpengaruh terhadap status gizi anak tersebut. Anak yang berumur kurang dari 24 bulan tidak diikutsertakan karena pada usia tersebut anak masih mengonsumsi ASI, di mana asupan energi, dan zat gizi makro lain dari ASI sangat sulit diperhitungkan. Berdasarkan hasil uji statistik $t$-test, hasil penelitian ini menunjukkan tidak terdapat hubungan yang bermakna antara umur dengan kegemukan pada anak usia 2459 bulan ( $p$ value $>0,05$ ). Meskipun demikian, terlihat bahwa rata-rata kegemukan pada anak dengan usia lebih muda lebih tinggi dibandingkan anak dengan usia lebih tua. Dengan kata lain, anak yang lebih muda berpeluang mengalami kegemukan lebih besar dibandingkan dengan anak yang lebih tua. Hal ini disebabkan karena anak yang usianya lebih muda dari rata-rata $(<40$ bulan) ternyata mengonsumsi asupan energi dan zat gizi (protein, lemak, dan karbohidrat) lebih tinggi dibandingkan anak yang usianya di atas ratarata ( $\geq 40$ bulan). Hasil penelitian ini sejalan dengan penelitian yang dilakukan oleh Rizqiya (2009), Riyanti (2002), Rijanti (2002), Anggraeni (2007), dan Widartika (2001) dan menemukan kecenderungan yang sama dimana anak yang lebih muda berpeluang lebih besar mengalami kegemukan dibandingkan anak yang lebih tua. $\mathrm{Hal}$ ini kemungkinan disebabkan oleh semakin bertambahnya aktivitas anak yang semakin besar dengan dilakukan sendiri tanpa bantuan orang lain termasuk orang tua. $23,24,25,26,27$

Hasil penelitian ini menunjukkan tidak terdapatnya hubungan yang bermakna antara jenis kelamin dengan kejadian kegemukan pada anak usia $24-59$ bulan ( $p$ value $>0,05$ ). Berbeda dengan penelitian yang dilakukan oleh Andriyani (2010) yang menemukan adanya hubungan yang signifikan antara jenis kelamin dengan kejadian kegemukan pada anak, dimana anak perempuan mempunyai kecenderungan 13,39 kali untuk mengalami obesitas dibandingkan anak laki-laki. ${ }^{28}$ Begitu pula halnya dengan penelitian yang dilakukan oleh Rizqiya (2009) yang menemukan adanya hubungan yang bermakna antara jenis kelamin 
dengan kejadian kegemukan pada anak. Kecenderungan anak laki-laki untuk mengalami kegemukan lebih besar 2,956 kali dibandingkan anak perempuan. ${ }^{23}$

Hasil penelitian ini mendapatkan proporsi kegemukan pada anak dengan asupan energi total per hari lebih dari $100 \%$ AKG lebih besar dibandingkan proporsi anak dengan asupan cukup $(70-100 \%$ AKG) dan kurang (< 70\% AKG). Hasil uji statistik menunjukkan tidak terdapatnya hubungan yang bermakna antara asupan energi dengan kejadian kegemukan pada anak usia 24-59 bulan ( $p$-value $>0,05$ ). Tidak terdapatnya hubungan yang bermakna dalam penelitian ini disebabkan karena pada anak-anak kebutuhan energi juga diperlukan untuk pembentukan jaringan baru. Selain itu, walaupun anak gemuk kemungkinan aktivitas fisiknya cukup bahkan lebih seiring bertambahnya usia sehingga asupan energi totalnya tidak terlalu berpengaruh terhadap kegemukan. Tetapi sayangnya aktivitas fisik tidak termasuk dalam variabel yang diteliti dalam penelitian ini, sehingga hubungan antara aktivitas fisik dengan asupan energi total dalam makanan tidak bisa dianalisis lebih lanjut. Alasan lain tidak terdapatnya hubungan adalah dikarenakan metode yang digunakan adalah food recall 24 jam yang hanya dilakukan satu hari saja, sehingga tidak menggambarkan asupan sehari-hari, karena ketidakseimbangan antara asupan energi dengan kebutuhan yang berlangsung dalam jangka waktu yang lama akan menimbulkan masalah kesehatan. ${ }^{15}$

Penelitian ini mendapatkan adanya hubungan yang bermakna antara asupan protein dengan kegemukan pada anak usia 2459 bulan ( $p$-value $<0,05$ ). Anak dengan asupan cukup (80-100\% AKG) cenderung bersifat protektif 0,829 kali lebih besar terhadap kegemukan dibandingkan anak dengan asupan lebih dari $100 \%$ AKG, dan anak dengan asupan kurang dari kebutuhan minimal asupan protein ( $<80 \%$ AKG) bersifat protektif 0,834 kali lebih besar dibandingkan anak dengan asupan lebih dari 100\% AKG. Dengan kata lain, anak dengan asupan cukup dan kurang berpeluang lebih besar untuk terlindung dari kegemukan dibandingkan anak dengan asupan protein tinggi. Terdapatnya hubungan yang bermakna antara asupan protein dengan kegemukan pada anak-anak disebabkan karena kelebihan protein akan diubah menjadi lemak dan akan disimpan di dalam tubuh. Makanan yang tinggi protein biasanya tinggi lemak. Dengan demikian, konsumsi protein secara berlebihan dapat menyebabkan kegemukan. ${ }^{17}$

Faktor lain terkait dengan kegemukan pada anak usia 24-59 bulan adalah asupan lemak. Makanan tinggi lemak akan menyebabkan kegemukan karena menghasilkan energi lebih besar. Setelah dikonsumsi, lemak makanan tidak mengalami perubahan metabolisme secepat karbohidrat dan protein. ${ }^{19}$ Penelitian ini menyimpulkan tidak ada hubungan yang bermakna antar asupan lemak dengan kejadian kegemukan pada anak usia 24-59 bulan ( $p$ value $>0,05$ ). Sejalan dengan penelitian yang dilakukan oleh Anggraeni (2007) yang tidak menemukan adanya hubungan antara asupan lemak dengan kegemukan pada anak, namun anak dengan asupan lemak tinggi berpeluang 1,4 kali lebih besar untuk mengalami kegemukan dibandingkan anak dengan asupan lemak cukup. ${ }^{26}$

Selanjutnya penelitian ini tidak dapat membuktikan adanya hubungan yang bermakna antara asupan karbohidrat dengan kegemukan pada anak usia 24-59 bulan ( $p$-value $>0,05$ ). Berbeda dengan penelitian yang dilakukan oleh Daryono (2003) yang menunjukkan adanya hubungan antara asupan karbohidrat dengan kejadian kegemukan pada anak, namun anak dengan asupan karbohidrat lebih dari 60 persen total energi berpeluang 5,51 kali lebih besar mengalami kegemukan dibandingkan anak dengan asupan karbohidrat cukup ( $\leq 60 \%$ AKG energi). ${ }^{18}$ Perbedaan hasil ini disebabkan oleh perbedaan cut off point yang digunakan. Tidak terdapatnya hubungan yang bermakna dalam penelitian ini kemungkinan disebabkan karena salah satu fungsi karbohidrat sebagai sumber energi utama sebagian besar berada di dalam sirkulasi darah sebagai glukosa untuk keperluan energi segera kaitannya dengan aktivitas fisik. ${ }^{17}$ Oleh karena itu, kelebihan karbohidrat yang diubah menjadi lemak untuk kemudian disimpan sebagai cadangan energi di dalam jaringan lemak sebagai faktor risiko kegemukan hanya sebagian kecil saja. Selain itu, sama halnya dengan asupan energi, dan lemak, metode food recall 24 jam yang hanya dilakukan satu hari saja tidak menggambarkan asupan anak seharihari yang sebenarnya. 
Hasil penelitian menunjukkan terdapat hubungan yang bermakna antara tingkat pendidikan ibu dengan kegemukan pada anak usia $24-59$ bulan ( $p$-value $<0,05)$. Anak dari ibu dengan tingkat pendidikan sedang bersifat protektif 0,065 kali lebih besar terhadap kegemukan dibandingkan anak dari ibu dengan tingkat pendidikan tinggi, dan anak dari ibu dengan tingkat pendidikan rendah bersifat protektif 0,879 kali lebih besar terhadap kegemukan dibandingkan anak dari ibu dengan tingkat pendidikan tinggi. Dengan kata lain anak dari ibu dengan tingkat pendidikan rendah dan sedang berpeluang lebih besar untuk terlindungi dari kegemukan dibandingkan anak dari ibu dengan tingkat pendidikan tinggi. Anak-anak dari ibu dengan latar belakang pendidikan lebih tinggi akan memiliki kesempatan hidup dan tumbuh lebih baik. ${ }^{29} \mathrm{lbu}$ dengan tingkat pendidikan tinggi, maka kesempatan ibu untuk bekerja guna menambah penghasilan keluarga semakin besar. Dengan demikian, semakin meningkatnya pendapatan, pemberian makanan yang berlebih dijadikan sebagai penebus rasa bersalah ibu karena telah meninggalkan anaknya di rumah untuk bekerja. Hal ini terlihat dari proporsi asupan energi dan zat gizi pada anak dari ibu dengan tingkat pendidikan tinggi lebih besar dibandingkan anak dari ibu dengan tingkat pendidikan sedang dan rendah.

Hasil penelitian juga mendapatkan hubungan yang bermakna antara status pekerjaan ibu dengan kegemukan pada anak usia 24-59 bulan ( $p$-value $<0,05)$, dimana proporsi ibu bekerja yang mempunyai anak gemuk sebesar 13,9 persen lebih tinggi dibandingkan dengan proporsi ibu yang tidak bekerja yang memiliki anak gemuk yaitu sebesar 11,9 persen. Peranan ibu sangat berpengaruh terhadap pembentukan kebiasaan makan anak-anak di dalam rumah. Ibu yang mempersiapkan segala sesuatunya mulai dari mengatur menu, berbelanja, memasak, menghidangkan makanan, serta mengajarkan tata cara makan kepada anak-anaknya. ${ }^{27}$

Distribusi pangan di keluarga merata bila setiap anggota keluarga mendapat jatah bagian makanan yang sesuai dengan tingkat kebutuhannya, menurut umur dan keadaan fisik serta jenis kelaminnya. ${ }^{30}$ Dibandingkan dengan keluarga kecil, jumlah anak yang kelaparan dari keluarga besar hampir 4 kali lebih besar. ${ }^{31}$ Hasil penelitian menunjukkan bahwa proporsi anak yang mengalami kegemukan dengan jumlah anggota keluarga $\leq 4$ orang sebesar 13,9 persen, lebih besar dibandingkan proporsi anak yang mengalami kegemukan dengan jumlah anggota keluarga $>4$ orang yaitu sebesar 11,8 persen. Hasil uji statistik menunjukkan adanya hubungan yang bermakna antara jumlah anggota keluarga dengan kegemukan pada anak usia $24-59$ bulan ( $p$-value $<0,05$ ), dimana anak dengan jumlah anggota keluarga $\leq 4$ orang berpeluang mengalami kegemukan 1,207 kali lebih besar dibandingkan anak dengan jumlah anggota keluarga $>4$ orang. Seandainya besar keluarga bertambah, maka pangan untuk setiap anak berkurang dan banyak orang tua tidak menyadari bahwa anak-anak yang lebih muda memerlukan pangan relatif lebih banyak daripada anak-anak yang lebih tua. ${ }^{32}$ Zat gizi yang diperlukan oleh anak-anak dan anggota keluarga yang masih muda pada umumnya lebih tinggi dari kebutuhan orang dewasa karena mereka sedang mengalami pertumbuhan yang sangat pesat. ${ }^{30}$

Semakin banyak jumlah anak berarti semakin besar pula tanggungan kepala rumah tangga dalam memenuhi kebutuhan material dan spiritual anggota rumah tangganya. Dengan demikian pembatasan jumlah anak perlu diperhatikan agar tercapai keluarga yang sejahtera. ${ }^{33}$ Hasil penelitian ini menunjukkan proporsi kegemukan pada anak yang di rumahnya terdapat jumlah balita satu anak lebih besar dibandingkan proporsi kegemukan pada anak yang di rumahnya terdapat jumlah balita lebih dari satu anak. Namun, hasil uji statistik menunjukkan tidak terdapat hubungan yang bermakna antara jumlah balita dalam keluarga dengan kejadian kegemukan pada anak usia 24-59 bulan ( $p$-value > 0,05). Hal ini sejalan dengan hasil penelitian yang dilaporkan oleh Daryono (2003) dimana tidak terdapatnya hubungan yang bermakna antara jumlah anak dengan kegemukan pada anak, namun terdapat peluang sebesar 1,93 kali lebih besar bagi anak tunggal untuk mengalami kegemukan dibandingkan dengan bukan anak tunggal. ${ }^{18}$

Selanjutnya hasil penelitian juga menunjukkan adanya hubungan yang bermakna antara wilayah tempat tinggal dengan kejadian kegemukan pada anak usia 24-59 bulan ( $p$ value $<0,05$ ). Anak yang tinggal di perkotaan berpeluang 1,330 kali lebih besar untuk 
mengalami kegemukan dibandingkan dengan anak yang tinggal di perdesaan. Proporsi kegemukan di perkotaan cenderung lebih besar dibandingkan di perdesaan. Hasil review Low, et al. (2009) membuktikan hal tersebut terjadi di negara berkembang, seperti di China dan Filipina pada tahun 2002.34 Sejalan dengan hal tersebut hasil SKRT (2004) juga menunjukkan prevalensi kegemukan pada balita di perkotaan $(4,3 \%)$ lebih besar dibandingkan dengan perdesaan (2,9\%). ${ }^{11}$ Begitu pula halnya dengan hasil Riskesdas 2007 yang menunjukkan prevalensi balita yang kegemukan lebih besar di perkotaan $(12,4 \%)$ dibandingkan dengan perdesaan $(12,0 \%) .^{12}$ Kondisi ini tidak jauh berbeda dari hasil Riskedas 2010 yang juga menyebutkan bahwa prevalensi kegemukan pada balita lebih besar di perkotaan $(14,6 \%)$ dibandingkan perdesaan $(13,4 \%){ }^{3}$

\section{SIMPULAN DAN SARAN}

\section{Simpulan}

Adanya hubungan yang bermakna antara asupan protein, tingkat pendidikan ibu, status pekerjaan ibu, jumlah anggota keluarga dan wilayah tempat tinggal dengan kegemukan pada anak usia 24-59 bulan di Indonesia tahun 2010. Namun, tidak ada hubungan yang bermakna antara umur, jenis kelamin, asupan energi, karbohidrat, asupan lemak, asupan serat, status gizi ibu, dan jumlah balita dengan kegemukan pada anak usia 24-59 bulan di Indonesia tahun 2010.

\section{Saran}

Penanganan masalah kegemukan pada anak diharapkan menjadi prioritas program oleh instansi kesehatan. Selain itu masyarakat terutama para ibu bekerja diharapkan dapat mendukung upaya-upaya yang dilakukan pemerintah dalam hal pencegahan dan penanganan kegemukan pada anak dengan cara menerapkan pola makan seimbang sesuai dengan PUGS. Diharapkan pula kepada para orang tua terutama ibu dan keluarga yang tinggal di perkotaan dapat menjadi contoh bagi anak-anaknya dalam hal kebiasaan makan sehari-hari dan selalu memantau pertumbuhan serta perkembangan anak-anaknya agar tumbuh secara optimal.

\section{RUJUKAN}

1. Hadi, H. Beban Ganda Masalah Gizi dan Implikasinya Terhadap Kebijakan Pembangunan Kesehatan Nasional. Pidato Pengukuhan Jabatan Guru Besar. Yogyakarta: Universitas Gajah Mada; 2005.

2. Soetjiningsih. Tumbuh Kembang Anak. Jakarta: Penerbit Buku Kedokteran EGC; 1995.

3. Kementerian Kesehatan RI. Riset Kesehatan Dasar 2010. Laporan Penelitian. Jakarta: Badan Litbang Kesehatan; 2010.

4. Samsudin. Gizi Lebih Pada Anak dan Masalahnya. Risalah Widyakarya Pangan dan Gizi V. Jakarta: Lembaga IImu Pengetahuan Indonesia; 1994.

5. Sjarif, D.R. Evaluasi dan Tata Laksana Obesitas pada Anak. Prosiding Simposium Temu IImiah Akbar. Jakarta: Fakultas Kedokteran Universitas Indonesia, Bagian IImu Penyakit Dalam; 2002.

6. World Health Oganization. Obesity and overweight. c2006; cited 3 Februari 2011. Available from: http://www.who.int/mediacentre/factsheets/f s311/en/. Fact sheet $N^{\circ} 311$

7. Khomsan, Ali. Pangan dan gizi untuk kesehatan. Jakarta: Rajagrafindo Persada; 2004.

8. World Health Oganization. Childhood overweight and obesity on the rise. c2009; cited 3 Februari 2011. Available from: http://www.who.int/dietphysicalactivity/child hood/en/

9. Finkelstein $\mathrm{EA}$, Khavjou $\mathrm{OA}$, Thompson $\mathrm{H}$, et al. Obesity and severe obesity forecasts through 2030. American Journal of preventive medicine 2012;42:563-70.

10. Ogden $C L$, Carroll MD, Kit BK, Flegal KM. Prevalence of obesity and trends in body mass index among US children and adolescents, 1999-2010. The Journal of the American Medical Association 2012;307:483-90.

11. Departemen Kesehatan RI. Survei Kesehatan Rumah Tangga: Status Kesehatan Masyarakat Indonesia. Jakarta: Badan Litbang Kesehatan; 2004. 
12. Departemen Kesehatan RI. Riset Kesehatan Dasar (Riskesdas) Indonesia 2007. Laporan Penelitian. Jakarta: Badan Litbang Kesehatan; 2008.

13. Supariasa, I.D.N, dkk. Penilaian Status Gizi. Jakarta: EGC; 2002.

14. Branca, Francesco. Obesity and Public Health. Department of Nutrition for Health and Development, WHO, Geneva. Global History Seminars. 17 November 2012.

15. Sartika, RAD. Keseimbangan Energi dalam Gizi dan Kesehatan Masyarakat Edisi Revisi. Departemen Gizi dan Kesehatan Masyarakat FKM-UI. Jakarta: Rajawali Pers; 2009.

16. Supriyatna, N. Faktor-faktor yang Berhubungan dengan Status Gizi Anak Usia 24 - 60 Bulan di Kecamatan Rajagaluh Kabupaten Majalengka tahun 2004. Skripsi. Depok: Fakultas Kesehatan Masyarakat Universitas Indonesia; 2004.

17. Almatsier, Sunita. Prinsip dasar ilmu gizi. Jakarta: PT. Gramedia Pustaka Utama; 2009.

18. Daryono. Hubungan Antara Konsumsi Makanan, Kebiasaan Makan, dan Faktorfaktor Lain dengan Status Gizi Anak Sekolah di SD Islam Al Falah Jambi Tahun 2003. Tesis. Depok: Fakultas Kesehatan Masyarakat Universitas Indonesia; 2003.

19. Arbai, AM. Peran Lemak Makanan dan Terjadinya Penyakit Degeneratif. Dalam: Pangan dan Gizi: Masalah, Program Intervensi dan Teknologi Tepat Guna. Bogor: Pergizi Pangan Indonesia; 2002.

20. Hastono, S.P. Analisis Data Kesehatan (Basic Data Analysis For Health Research Training). Depok: Fakultas Kesehatan Masyarakat Universitas Indonesia; 2007.

21. Gibson, RS. Principles of Nutritional Assessment. 2nd Edition. New York: Oxford University Press, 2005.

22. Ness, A.R. (2004) The Avon Longitudinal Study of Parents and Children (ALSPAC) a resource for the study of the environmental determinants of childhood obesity. European Journal of Endocrinology. 2004; 151( U141-U149).
23. Rizqiya, F. Analisis Faktor-faktor yang Berhubungan dengan Kegemukan Anak Usia Prasekolah di TK Mardi Yuana Depok Tahun 2009. Skripsi. Depok: Fakultas Kesehatan Masyarakat Universitas Indonesia; 2009.

24. Riyanti, A. Riwayat Pemberian ASI dn Faktor-faktor Lain yang Berhubungan dengan Status Gizi Anak Prasekolah di TKI Al Azhar Kemang Jakarta Selatan Tahun 2002. Skripsi. Depok: Fakultas Kesehatan Masyarakat Universitas Indonesia; 2002.

25. Rijanti. Hubungan konsumsi makanan dan faktor-faktor lain dengan status gizi anak sekolah di SD PSKD Kwitang VIII Depok Tahun 2001. Tesis. Depok: Fakultas Kesehatan Masyarakat Universitas Indonesia; 2002.

26. Anggraeni, A.N. Asupan Energi, Serat, Dan Konsumsi Lemak Serta Faktor Lain Sebagai Indikator Risiko Obesitas pada Anak Pra Sekolah di TK Pembangunan Jaya Bintaro Tangerang Tahun 2007. Skripsi. Depok: Fakultas Kesehatan Masyarakat Universitas Indonesia; 2007.

27. Widartika. Faktor-faktor yang berhubungan dengan obesitas pd anak TK dan SD terpilih di kotamadya Bandung Tahun 1999. Analisis data sekunder di Kotamdya Bandung. Skripsi. Depok: Fakultas Kesehatan Masyarakat Universitas Indonesia; 2001

28. Andriyani, F. Faktor-faktor yang Berhubungan dengan Kejadian Obesitas pada Anak Sekolah di SD Pelita Jakarta Tahun 2010. Skripsi. Depok: Fakultas Kesehatan Masyarakat Universitas Indonesia; 2010.

29. Lesda, M, dkk. Hubungan Karakteristik Siswa dan Orangtua dengan Status Gizi Siswa Sekolah dasar Negeri KB 4 Kota Banjarmasin. Penelitian Gizi Makanan 2006, 29(2): 98 - 106.

30. Sediaoetama, A.J. IImu Gizi. Jakarta: Penerbit Dian Rakyat; 2008.

31. Berg, Alan. Peranan Gizi Dalam Pembangunan Nasional. Jakarta: Penerbit CV. Rajawali; 1986. 
32. Suhardjo. Berbagai Cara Pendidikan Gizi. Jakarta: Penerbit Bumi Aksara; 2003.

33. Badan Pusat Statistik. Statistik Kesejahteraan Rakyat 2009. Jakarta: Badan Pusat Statistik, 2009.
34. Low, et al., Review on Epidemic of Obesity. Annals Academy of Medicine. 2009; 38(1):57-65. 